\title{
Effect of Bank Merger on the Shareholders Wealth and Post-Merger Situation of Nepalese Banking Industry
}

\author{
Manoj Kumar Bhatta \\ Nepal Campus, Shinawatra University, Bangkok, Thailand \\ manojkbhatta@gmail.com
}

\begin{abstract}
This research studies the effect of independent variables such as cost efficiency, ROA, ROE and Capital on dependent variable EPS of the merged bank in Nepal. Various statistical tools such as mean standard deviation, correlation, regression were employed to measure the effect of bank merger on the shareholders wealth. Based on the result of study, except ROA, no other independent variable under study showed any impact on earnings per share. The superior bank shareholders are not getting what they deserve and inferior bank shareholders get more than they deserve after the post-merger. It is also finding out that external factors such as earthquake, border blockade and political instability highly affects the shareholders earnings.
\end{abstract}

Keywords: Shareholders wealth, Cost Efficiency, ROA, ROE, Capital base

\section{Introduction}

Background of the Study: In 1937 AD, Nepal Bank Limited was established as the first commercial bank in the history of Nepalese banking industry. It was the jointly owned bank of the government and general public. In these more than seven decades, there were many ups and downs in the Nepalese financial system. It has faced various experiments to advance the system and changes in policies and regulations. After 1990s financial sector was liberalized and resulted into entry of many new banks in the Nepalese market. By the end of 2015, altogether 241 banks and non- bank financial institutions licensed by NRB were in operation. Out of them, 29 are " $\mathrm{A}$ " class commercial banks, 76 "B" class development banks, 48 "C" class finance companies, 38 "D" class micro-credit development banks, 15 saving and credit co-operatives and 27 NGOs. Also, the total banks branches reached to 3,838 (NRB Report, 2015). Nepal's financial market opened up for international investment in January 2010 and merger by-laws came in place in May 2011 (Adhikari, 2014). This scholar has closely observed that the merger transactions are increasing in Nepal over the past few years - almost only since year 2011- with an aim to create wealth for shareholders, developing efficient and reliable banking that can compete with new entrants from foreign. In recent Nepalese scenario mergers \& acquisitions is playing an important role in shaping competent and advance banking in Nepal.

Roborts, Wallace and Moles (2010) have defined merger as a combination of two companies to form a new company. Onikoyi and Awolusi (2009) have concluded that going by market value of the merged banks, shareholders wealth creation has been decreased, in some cases completely destroyed. According to these scholars, the noticeable problems that challenge the shareholders return of the merged banks involved decrease of market prices of their shares on the stock market, reduction of shareholders money due to of losses incurred from merger and lack of dividend pay out to the owners. Capital accumulation has important role in accelerating the economic growth, which in terms is basically determined, among others, by saving and investment propensities. The dimension of commercial banks transactions mirror the economic movement in the country. The financial system in Nepal has from a narrow, repressed regime till the eighties to a dynamic expanding sector in the nineties. Indicators of the last decade shown that the sector has growth both quantitatively and qualitatively and there will be 15 to 20 commercial banks with combined paid-up capital of around NRs 120 billion by 2017/18. Going through the Nepal Rastra Bank (NRB) monetary policy of the fiscal year 2015/16, NRB has raised the minimum capital requirement for banks to NRs 8 billion from current NRs 2 billion. In this context the commercial banks are forced to go for merging and acquisition. At the same time, it becomes immense important to see whether the performance of these merged banks and financial institutions is creating wealth to their shareholder and impact of merger on return to shareholder of the merged banks is the pinning point for the present researcher in this paper. 
Problem Statements: Economic liberalization and privatization policy adopted by the government has open up the opportunity and threat to the banking sectors. As a result, we see a rapid growth in the numbers of commercial banks in the country and of course, the rapid increment in numbers of commercial banks in small country like Nepal has created tough competition among bankers. While operating after merger there may be different kind of changes in the position of organization. Change may take place as regard net worth, deposit collection, investment, income generation, expenditure etc. In this research work it would be relevant to analyze the direction as well as magnitude of such change that has taken place during the study period. This research work attempts to know whether the change pattern or direction of changes as regards various trends of the concerned banks is beneficial to the shareholders and to the economy or not. This study will try to seek the answers relating to the merger of banks and the consequences to the shareholders return and to the economy as a whole. Do merger really enhance the shareholders' value?

Research Questions: Taking into consideration the background of the study, missing link, objectives and significance, the present researcher has composed a set of four research questions (RQs) with an aim to access the overall impact of merger on shareholders wealth in the Nepalese Banking industry.

RQ 1: To what extent are the shareholders of the bank following merger getting the worth they deserve?

RQ 2: what are the best practices in the global context and what could be the best option in Nepalese context?

$\mathrm{RQ}$ 3: Is it really true that shareholders wealth is increasing as a result of merger of the banks?

$\mathrm{RQ} 4$ : Is there any alternative for the merger?

Research Objectives: The general objective of the study is to assess the effect of merger in shareholders' wealth creation. To attain the main objective, the present researcher will further explore following aspects as part of specific objectives of the enquiry:

- Know the association of capital base increment and shareholders' wealth maximization.

- Explore the best practices of merger in the global context.

- Investigate the relationship between merged banks' ROA \& ROE and its impact on shareholders' wealth.

- Uncover the alternatives to the merger.

- Know the relationship of banks' cost savings and shareholders' wealth.

Research Significance: Analyzing the above situation, the present researcher could discover the impact of merger in the context of Nepal. The researcher could find the situation of merger in Nepal that no study has yet been done regarding this. The impact and significance of merger on shareholders' wealth creation will be addressed in this study. Moreover, such a study would serve instrumental in exploring global best practices in merger of financial institutions and also uncover alternatives to merger. In the context of Nepal, this is a relatively new topic. This study will try to find out the effects of merger in terms of capital base, revenue and cost saving on shareholders wealth creation. As the present researcher has been determined to develop professional career in this sector, such an exposure would serve instrumental to understand the reality. So, this study is expected to be useful to various concerned persons or groups such as management, shareholders, depositors, creditors, investors, stock brokers, policy makers, researchers and so on.

\section{Literature Review}

Merger and its Concept: Mergers and acquisitions are capital investment projects in which a business expands externally by acquiring or amalgamating with another related or non-related firm. Motivations for mergers are different. Some go for merger for superior management skills, for the technical capabilities, new market entrant, and to achieve operating economies. Scholars have found out that managerial motives are important determining factor for the outcome of the merger.

Motives of Companies Merger: Based on the literature review, it can be concluded that merger has been driven by many factors and rationales. The major motives that drive for merger in Nepalese context are as follows:

For Synergy: When two or more firms are combined to form one superior and combined value is more than individual than synergy is achieved Jensen and Ruback (1983). It can be shown as $2+2=5$. Synergy can be 
achieved from operational efficiency or by the financial efficiency. Economies of scale are can help in reducing cost and creates synergy. Wang and Xie, (2009) concluded that corporate governance influences merger synergies which are earlier divided among the firms.

Efficiency gains: Efficiency is using resources in such a way as to maximize the production of goods and services. Merger brings greater efficiency to the domestic banking with greater economies of scale that help in building strong and more competitive banking industry in the country.

For Growth: Growth is one of the major motives for merger. After 1990s trend of merger, where size matter to compete play important role for merging. Growth is seems in terms of size, capital and resources. Banks can grow either by acquiring another bank for more opportunity to grow and expand. Merger for growth helps in reducing threat in the market and future potential competitors.

Merger History: History of merger can been traced back from nineteenth century in the United States and after that it occurred in waves. After that each movement of merger was observed based on the nature of merger and particular industries. In 1900s when first wave of merger started it was characterized as horizontal merger done for creating monopoly According to Lipton, in 1920s second phase of merger was seen mainly in the US with vertical merger where giant automobile manufacturing companies. Third wave of merger was seen in 1960s where conglomerates merged to diversify their business and to enter into different sector of business and research. In 1980s fourth wave of merger was seen which was called disciplinary merger where most of the affected financial institutions merge to overcome weaknesses. After 1990s, next wave was observed where firms merger for size. To compete in the market, size does matter concept emerged.

Merger in Nepal: Article 68 of Banking and Financial Institutions Act (2063) opened the door for the merger in Nepal by clearly mentioning that one company can go for merger with another if procedures are fulfilled, though it do not describe acquisition. It is a common phenomenon that one of the basic goals of a firm is to increase the value of the firm or shareholders wealth. Nepal Economic Forum, 2010 also highlighted merging as one of the daunting tasks for the financial institutions in many respects, especially to maintain the sentiment of shareholders, management committee, employees, and the governing institutions. Nepal Rastra Bank (NRB) unified directives 2072 based on revised framework of international convergence for capital measurements and capital standards states that minimum capital requirement is necessary to increase to mitigate the operational risk and banking failure.

The past studies on efficiency of merger have seen elaborative and consistent. Many of the research scholars supports the conclusion that merger create value and are economically efficient. Most of the results strongly support the conclusion that mergers are profitable and are socially needed for economy growth (Caves, 2003). Doytch \& Cakan (2011) studied the merger growth effect both in the domestic market and cross boarder in terms of sectors and on the overall economy. The scholar concludes that there is no support to the hypothesis. Merger activity does not any support the economic growth, except service industry. They found out that merger of both financial and non-financial services has positive effect on growth and negative effect on manufacturing and other industry growth rates. When analyzing impact of merger in aggregate economy growth seems negative ( Doytch \& Cakan , 2011). Scholars have also found out that stock performance of the bank is not the deciding factor for bank growth. Many times the stock value is the result of speculation, wrong expectations or a game of luck. The banks with better profitability ratios in comparison to the industry average shows banks are profitable as well as more competitive within the industry (Maditinos, Theriou, \& Demetriades, 2009). Few of the scholars had conducted a systematic empirical analysis of merger activity in UK for the period of thirty years data. They analyze the effects of related and unrelated mergers and hostile versus friendly mergers. It was concluded that merger activities were followed by substantial and statistically significant employment and increase in efficiency after the post-merger phase (Conyon, Girma, Thompson, \& Wright, 2000).

Omah, Okolie and Durowoju (2013) have come up with the finding that operating expenses, profit margin, return on capital employed and expenses ratio are the most influencing factors on shareholders wealth creation. While analyzing the inter company and intra company results, it shows that there is marginal 
positive effect on shareholders wealth creation. Omah, Okolie and Durowoju (2013) concludes that motive of merger is to enhance the synergy. In this study, an attempt has been done to analyze the merger impact on shareholders wealth of the companies which have gone for merger during the period of 2001 to 2010. A scholar has stated that after the economic liberalization in 1984, banking sector got a lot of opportunities to expand, grow and introduce modern technologies in banking service. A study by Juma, Wawire, Byaruhanga, Okaka, and Odera (2012) has revealed that merger significantly influences shareholders value, creating more value than those that have not gone for merger. Merged banks were supposed to have better results than the overall sector.

Bank Overview: Global IME Bank Ltd. Emerged as a successful merger of Global Bank Ltd. An A class commercial bank with IME Financial Institutions and Lord Buddha Finance Ltd. C class finance companies in the year 2012. In 2013, Social Development Bank and Gulmi Bikas Bank merged with Global IME Bank. In year 2014, A class commercial bank i.e. Commerz \& Trust Bank merge with Global IME Bank (Annual Report 2014). NIC ASIA Bank was established in the year 1998. The bank was retiled as NIC ASIA bank after the merger of NIC Bank Ltd. and Bank of Asia Nepal on 30th June 2013. This was one of the successful mergers in the history of Nepalese commercial banks merger history. After the post-merger phase, bank was able to manage the transition very smoothly receiving praises from its stakeholders.

\section{Figure 1: Conceptual Framework}

\section{Variables Relationship}

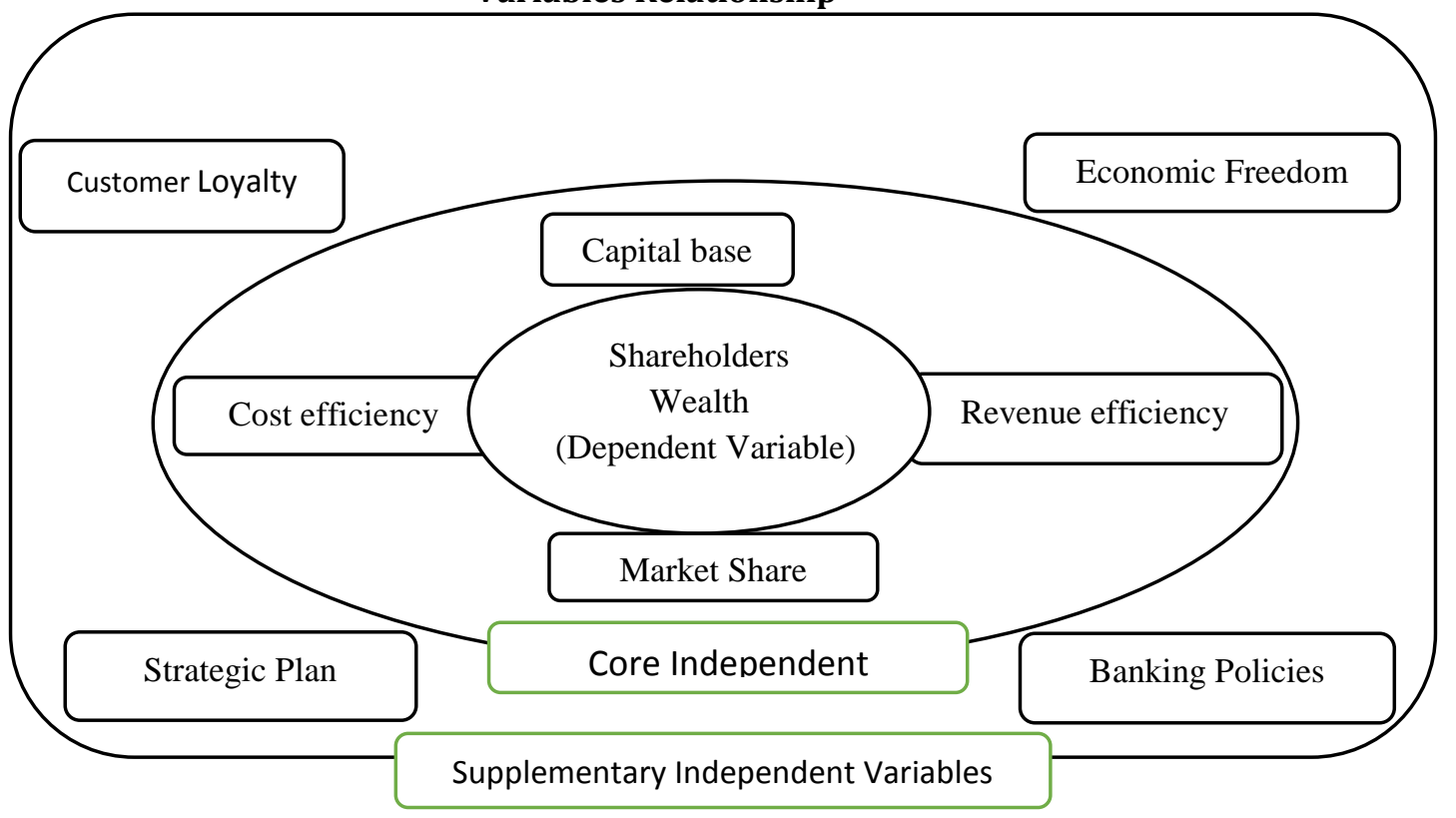

Shareholders Wealth Maximization: Wealth creation or maximization refers to the changes in the wealth of the shareholders on annual basis. Shareholders wealth changes mostly from changes in stock prices, dividend paid, and equity raised during the period (Institute of management accountants, 1997). Oladipupo and Okafor in 2011 point out that the fundamental and traditional objective of business organizations is to maximize the shareholders wealth.

Capital Base: Capital bases the back bone of the banking operation which supports business. The importance of the adequate capital in banks cannot be overemphasized. It is an essential element that enhances banks confidentiality and permits banks in banking business. Having more capital means banks can bear more losses and it can sustain without going bankrupt.

Revenue Efficiency measured in terms of ROA and ROE: ROA and ROE are the measuring tool for the revenue efficiency. It indicates how well a bank perform in terms of profit with other banks in the same period. ROA and ROE of the bank help in determining the revenue efficiency of the bank. 
Cost Efficiency: Bank cost efficiency is also the major factor influencing the shareholders wealth. Banks that shows higher cost efficiency might be able to generate greater profits than inefficient banks. Cost is also a major factor in determining operation efficiency and increasing profit.

\section{Methodology}

In this study banks that have gone for merger in the period of 2011 to 2015 are taken into consideration. In Nepalese Banking only 2 ' $A$ ' class commercial banks completed the merger and operations. The empirical analysis of the merged banks has been done with through analysis of pre-merger and post-merger to give clear view on their success and failure. There are about 3 commercial banks that completed merger during the period. Out of them 2 were selected for the study. In total 9 banks and financial institutions are merged to form these 2 commercial banks. Research is based on the secondary data analyses. The annual report of ' $\mathrm{A}$ ' class merged banks are analyzed. The gain and loss of shareholders in terms of earnings per share has been evaluated. The major analyses is whether the shareholders of superior banks getting what they deserve or not. Data Analysis: Using quantitative methods, data from the financial statements of the concerned banks were used to calculate the various financial ratios that are proxies for shareholder wealth measurement. Ratios such as: Earnings per share, ROA, ROE, Capital base, and Cost efficiency. Correlation and Regression coefficient is calculated for the analysis of the data. Assets and ROA, Equity and ROE is analyzed and its increasing and decreasing order has been calculated. Merged banks that exist are taken as superior banks and after merger that do not exist are considered as inferior bank.

Dependent and Independent Variables: In this study shareholders wealth (SHW) is taken as a dependent variable. This is the earnings per share value of banks as result of merger after 2013.

Calculation of dependent variable: SHW (EPS) =Net profit after tax/No. of shareholders Independent Variable

There are four independent variables used for the analysis of the merger effect on shareholders wealth. For the purpose of this study, Capital Base (CB), ROA, ROE and Cost Efficiency (CE) are used as independent variables.

Calculations of Independent Variables

Capital base (CB) $=$ Equity /Total Assets

ROE $=$ Net Profit after tax/Total Equity

ROA $=$ Net Profit after tax/Total Assets

Cost Efficiency $(\mathrm{CE})=$ Operating expenses/Operating revenue

\section{Data Collection and Analysis}

In this research, major secondary sources of data was collected from the NIC ASIA Bank and Global IME Bank and other merged commercial banks as these are only the banks that have an operating history of at least two years before and after merger. Personal interview with the managers and CEOs was taken as the primary sources. Quantitative techniques such as mean value, standard deviation, coefficient of correlation and regression were calculated. Different measures of central tendencies were the outcomes of descriptive research design which was normally executed through surveys, interviews, and annual reports analysis. The annual report of all the merged companies before the merger and after the merger were thoroughly analyzed. 
Figure 2: Bank growth

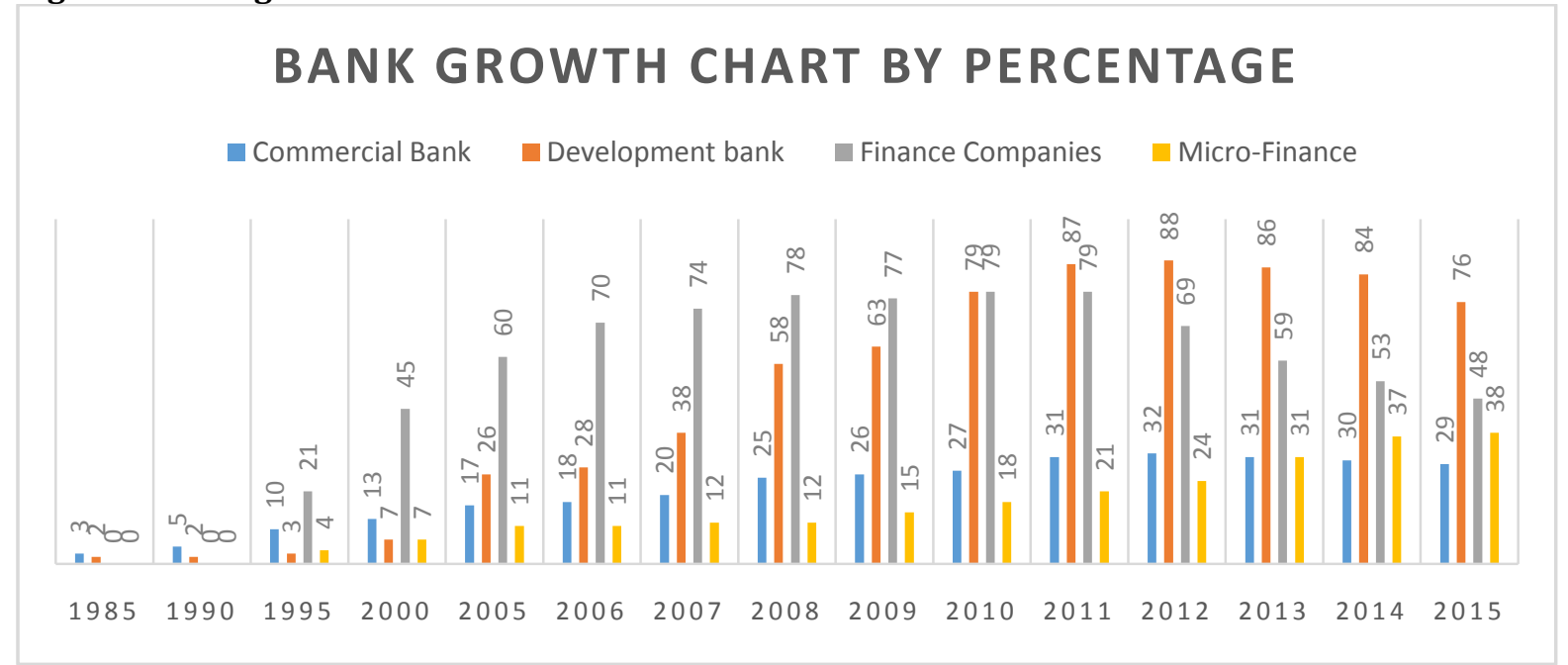

(Source: NRB Bank Supervision Report, 2015)

The chart above shows the increasing trend of bank and financial institutions growth in Nepal before and after the year 2011 when Nepal open the door for the international community in banking industry. Nepal Rastra Bank (NRB) also motivate banks to go for the merger to increase the capital base and strengthen national banking sector. With the end of 2015, 6 commercial banks merge and form 3 commercial banks. Along with this 12 development banks and 31 finance companies has been merged with commercial banks, development banks and with oneself. The target of NRB to meet Rs. 8 billion for commercial banks, Rs. 2 billion for development banks and Rs. 1 billion for finance companies by year 2016/17, are unable to accomplish and it shows that still many of the banks are in the merger process. Year 2011 was the year of highest banks and financial institutions in the country.

\section{Bank Performance Indices}

Superior Bank: Financial year 2013-14 exhibited a year with change towards growth for Global IME Bank. This year shows various accomplishments, a thriving performance post-merger with Social Development Bank Limited and Gulmi Bikas Bank Limited, acquisition majority shares of Elite Capital Limited and change of its name to Global IME Capital, a successful merger with Commerz and Trust Bank Nepal Limited. (Annual Report 2014). Financial Year 2014-15 shows the slowdown in the performance level of the bank. Earnings per share decreases with decrease in ROA and ROE. Year 2014 show the highest earning per share.

Table 1: highest earning per share

\begin{tabular}{llllll}
\multicolumn{2}{l}{ Global IME Bank } & & & \\
YEAR & EPS & CE Ratio & Capital & ROA & ROE \\
\hline 2015 & 15.58 & $43.54 \%$ & 0.106 & 1.39 & 13.06 \\
2014 & 19.57 & 42.65 & 0.102 & 1.62 & 16 \\
2013 & 16.15 & 42.10 & 0.0823 & 1.15 & 14 \\
2012 & 11.79 & 50.55 & 0.0827 & 0.87 & 10 \\
2011 & 14.06 & 45.75 & 0.097 & 1.28 & 13 \\
2010 & 4.95 & 46.41 & 0.088 & 0.42 & 5 \\
2009 & 2.63 & 59.88 & 0.083 & 0.26 & 3 \\
\hline
\end{tabular}


The year 2014/15 was yet another challenging year, with persistent high liquidity, moderate credit growth, and political uncertainty, with the entire last quarter of the year lost due to the devastating earthquake that struck on April 25, 2015, and its subsequent aftershocks. NIC ASIA Bank report analyses and calculation of various efficiency ratios show year 2013 was better than year 2014 and even better than 2015. In year 2015 bank performance slow down highly.

Table 2: bank performance

\begin{tabular}{llllll}
\multicolumn{2}{l}{ NIC Asia Bank } \\
YEAR & EPS & CE Ratio & Capital base & ROA & ROE \\
\hline 2015 & 25.59 & 41.58 & 0.092 & 1.21 & 13.05 \\
2014 & 35.98 & 34.13 & 0.095 & 1.71 & 15.93 \\
2013 & 47.41 & 30.45 & 0.094 & 1.78 & 14.63 \\
2012 & 29.87 & 37.04 & 0.081 & 1.64 & 19 \\
2011 & 37.80 & 29.19 & 0.090 & 2.34 & 28.09 \\
2010 & 34.30 & 26.72 & 0.087 & 2.30 & 27.09 \\
2009 & 27.83 & 27.08 & 0.088 & 1.88 & 24.23 \\
\hline
\end{tabular}

Inferior Bank: Here those banks which are amalgamated into another bank and whose name do not exist in today banking are referred to as inferior banks. Low performance level and not able to maintain the NRB target on self are inferior. These banks fully accept and amalgamated into the better performing banks which are here known as superior banks. Commerz and Trust Bank came into operation on the year 2009. It was merged with Global IME Bank in the year 2014. The process of merger was initiated in the year 2013 and completed in 2014. Due to the announcement of merger with Global IME Bank in the year 2013 Commerz and Trust bank has experienced tremendous growth except ROE. Its shareholders achieve more after the postmerger than the pre-merger period.

Table 3: post-merger and pre-merger period

\begin{tabular}{|c|c|c|c|c|}
\hline \multicolumn{5}{|c|}{ Commerz and Trust Bank } \\
\hline YEAR & EPS & CE Ratio & ROA & ROE \\
\hline 2015 & 15.58 & $43.54 \%$ & 1.39 & 1.39 \\
\hline 2014 & 19.57 & 42.65 & 1.62 & 1.62 \\
\hline 2013 & 16.15 & 42.10 & 1.15 & 1.15 \\
\hline 2012 & 8.63 & 36.63 & 0.3 & 1.75 \\
\hline 2011 & 10.49 & 75.25 & 0.19 & 1.05 \\
\hline 2010 & 13.86 & 57.61 & 0.55 & 1.6 \\
\hline 2009 & 6.15 & & & \\
\hline
\end{tabular}

Earnings per share seems highest in the year 2014 with Rs. 19.57 per share though it was decreased in the year 2015. Cost efficiency ratio has been maintained and ROA is also in increasing trend except in year 2015. Bank of Asia came into operation from October 2007. Bank performance index shows that there is huge difference and gain to the shareholders after the merger. Low performing bank shareholders turns out to be the high earning shareholders. 
Table 4: Shareholder Earning

\begin{tabular}{lllll}
\hline $\begin{array}{l}\text { Bank of Asia } \\
\text { YEAR }\end{array}$ & EPS & CE Ratio & ROA & ROE \\
\hline 2015 & 25.59 & 41.58 & 1.21 & 13.05 \\
2014 & 35.98 & 34.13 & 1.71 & 15.93 \\
2013 & 47.41 & 30.45 & 1.78 & 14.63 \\
2012 & 8.63 & 45.62 & 0.97 & 7.93 \\
2011 & 10.49 & 39.66 & 1.26 & 9.74 \\
2010 & 13.86 & 40.56 & 1.53 & 13.11 \\
2009 & 6.15 & 49.46 & 0.77 & 6.05 \\
\hline
\end{tabular}

Bank of Asia merged with NIC Bank in the year 2013. Earnings per share increased with 445 percent. Likewise ROA, ROE and cost efficiency has been improved quite a lot. Bank of Asia shareholders earn very high return after the bank was merged with NIC Bank. Researcher has used SPSS data processing to obtain data such as mean and standard deviation. The following is a table of the descriptive statistics result:

Table 5: Descriptive Statistics

\begin{tabular}{llll}
\hline & $\mathbf{N}$ & Mean & Std. Deviation \\
\hline AVG ROA & 7 & 1.4179 & .25227 \\
AVG ROE & 7 & 15.4343 & 2.51232 \\
AVG CE Ratio & 7 & 39.7907 & 3.35229 \\
AVG CB Ratio & 7 & .0904 & .00642 \\
AVG EPS & 7 & 23.1079 & 5.63763 \\
Valid N (list wise) & 7 & & \\
\hline
\end{tabular}

Table 6: Correlation

\begin{tabular}{|c|c|c|c|c|c|c|}
\hline & & AVG ROA & AVG ROE & $\begin{array}{l}\text { AVG } \\
\text { Ratio }\end{array}$ & $\begin{array}{c}\text { CEAVG } \\
\text { Ratio }\end{array}$ & CAAVGEPS \\
\hline \multirow{2}{*}{ AVGROA } & Pearson Correlation & 1 & & & & \\
\hline & Sig. (2-tailed) & & & & & \\
\hline \multirow{2}{*}{ AVGROE } & Pearson Correlation & $.819 *$ & 1 & & & \\
\hline & Sig. (2-tailed) & .024 & & & & \\
\hline \multirow{2}{*}{ AVG CE Ratio } & Pearson Correlation & -.689 & -.548 & 1 & & \\
\hline & Sig. (2-tailed) & .087 & .203 & & & \\
\hline \multirow{2}{*}{ AVG CA Ratio } & Pearson Correlation & .516 & .150 & -.207 & 1 & \\
\hline & Sig. (2-tailed) & .236 & .748 & .655 & & \\
\hline \multirow{2}{*}{ AVGEPS } & Pearson Correlation & .736 & .324 & -.684 & .314 & 1 \\
\hline & Sig. (2-tailed) & .059 & .478 & .090 & .493 & \\
\hline
\end{tabular}

*. Correlation is significant at the 0.05 level (2-tailed).

(Source: Data processed SPSS version 20)

Above correlation table revels the relationship among core variables. There is a positive relationship between the return on assets (ROA) and the organizations' earnings per share (EPS) ( $\left.r=0.736^{*}, p=0.059\right)$. This relationship implies that ROA influences shareholders' wealth positively. It shows that EPS and ROA are moderately higher positive correlation. Also, there is a positive relationship between EPS and ROE ( $\mathrm{r}=0.324^{*}$, $\mathrm{p}=0.478$ ). This signifies that in order to maximize shareholders' wealth, an organization should seek to maximize ROE (Heffernan, 2005). Consequently, a negative relationship exist between the EPS and cost efficiency ratio (CER) ( $\mathrm{r}=-0.684^{*}, \mathrm{p}=0.098$ ). This implies that shareholders earnings and CFR are related although negatively and that an organization seeking to maximize shareholder value should struggle to reduce the CER. 
Table 7: Model Summery

\begin{tabular}{lllll}
\hline Model & R & R Square & Adjusted R Square & Std. Error of the estimate \\
\hline 1 & $.978 \mathrm{a}$ & .957 & .872 & 2.02005
\end{tabular}

a. Predictors: (Constant), AVG CA Ratio, AVG ROE, AVG CE Ratio, AVG ROA

Table 8: Coefficients a

\begin{tabular}{|c|c|c|c|c|c|}
\hline \multirow[t]{2}{*}{ Model } & \multicolumn{2}{|c|}{ Unstandardized Coefficients } & \multirow{2}{*}{$\begin{array}{l}\text { Standardized } \\
\text { Coefficients } \\
\text { Beta }\end{array}$} & \multirow[t]{2}{*}{$\mathbf{T}$} & \multirow[t]{2}{*}{ Sig. } \\
\hline & B & Std. Error & & & \\
\hline (Constant) & 57.446 & 20.774 & & 2.765 & .110 \\
\hline AVGROA & 43.658 & 9.474 & 1.954 & 4.608 & .044 \\
\hline AVGROE & -2.861 & .701 & -1.275 & -4.079 & .055 \\
\hline AVG CE Ratio & -.246 & .358 & -.146 & -.687 & .563 \\
\hline AVG CB Ratio & -467.771 & 189.416 & -.533 & -2.470 & .132 \\
\hline
\end{tabular}

a. Dependent Variable: AVG EPS

The regression coefficient of ROA (b1) is 43.658 which implies that an increase of one rupee in ROA increase EPS by rupees 43.658 on average if the other factors remain constant. The regression coefficient of ROE (b2) is -2.861 which also implies that increase in one rupee of ROE decrease EPS by 2.861 on average if the other variables remain constant. Similarly the regression coefficient of CER (b3) is -0.246 which implies that an increase of one rupee in CER decrease EPS by 0.246 rupees. But the estimates of b1, b2 and b3 may vary by 9.474, $0.701,0.358$ and 189.416 respectively as indicated by standard error. The significant $\mathrm{t}$-values and significant F-values are greater than 5\% level for ROE, CER and CB, and less than 5\% for ROA. So coefficients mentioned above are not statistically significant for ROE, CER and CA and significant for ROA. However, there is positive relationship with ROA indicated by the coefficient $\mathrm{B}=43.65$ and $\beta=1.954$. This implies that the ROA influences the shareholder value positively representing that in order to improve or grow shareholder value; banks should seek to improve ROA and reduce CER.

\section{Interpretation and Discussion of Findings}

Pearson Correlation Coefficient (R): The Pearson correlation coefficient (R) of .978 shows a positive correlation. The strength of the relationship between shareholders wealth and capital base, ROA, ROE and cost savings is strong. But this prediction may vary by 2.02 as shown by the figure in the column of standard error of estimate (SEE).

Coefficient of Determination (R2): The results presented above indicates that R2 value of 0.957 indicates that about $95.7 \%$ of the total systematic variations in the shareholders wealth were due to of the variations in capital base, ROA, ROE, and cost efficiency. This means that only about $4.3 \%$ of the systematic variations in the shareholders wealth are left unexplained hence captured by the external factors.

Major Findings: Capital base increase can enhance earnings by reducing the expected cost including bankruptcy as cited by (Asikhia \& Adeyinka, 2013)but in this though EPS and Capital base are positively related but impact of capital base very low. With the increase in capital base EPS is increasing by 0.21.ROA has positive impact on earnings per share and ROE has negative impact. Increase in ROA has helped to increase the EPS of the shareholders whereas ROE has no contribution on the EPS of the banks. Global IME bank has increased its capital base to Rs.7323 lakhs. It still need Rs.677 lakhs to meet the target of NRB by next year. Every year capital has been increased continuously. Earnings per share is fluctuating every year but in increasing trend. In year 2015 EPS downfall to Rs. 15.58 per share. Cost efficiency is good but not satisfactory. Though CE Ratio is decreasing from the last few years but in year 2015 it again shows increment. 
Return on Assets (ROA) has been increased since merger but in year 2015 it also decreased. Return on Equity (ROE) also decreased in year 2015 but it has been increased after merger in year 2013.

The Bank's earnings per share stood at Rs. 25.59 which is around 28.89 percent decrease than year 2014 and 46 percent less than year 2013. Return on equity at $13.05 \%$ against the industry average of Rs. 27.04 and $17.91 \%$, respectively. In year 2015 bank capital base increased to Rs. 5576 lakhs but far from meeting the target of NRB by 2016. ROA has also been decreased in year 2015 but year 2014 shows the highest growth after merger. ROE was decreased after merger. Pre-merger ROE was better than post-merger ROE. EPS ratio has been increased which is good sign for the bank. Cost efficiency ratio has been increased which is not the good sign for the bank. Pre-merger CE ratio was better than post-merger. Study showed that shareholders of the superior banks are not getting what they deserve. It is shown from the earnings per share of the superior and inferior bank EPS of the consecutive years. Inferior banks shareholders are earning more than the shareholders of the superior banks. It is shown that superior banks are not getting what they deserve after merger.

\section{Conclusion and Future Implications}

The major implication of the findings is that new capital brought in by shareholders of the merged banks increase the banks operation in post-merger era. Size has been increased. Revenue was also on increasing trend while cost of operations reduced slightly for the superior banks and mostly by the inferior banks due to elimination of redundancy. Mergers led to changes in banks share ownership. Bank efficiency increases with more competent and merged ideas. Excess capital made able to compete favorably with foreign banks that are willing to enter into the Nepalese market very soon. Financial performance of the banks and the result of the findings are affected by the external factor in the year 2015.

- Due to the devastating earthquake many banks has to suffer huge loss. It is the one of the main reason despite the merger in year 2015 banks incur loss and slowdown in the major performance index.

- Border blockade by the India for more than six months also seriously affect the performance of the bank.

- Another is the political instability and various ups and downs. Especially in the Terai region local political parties forced the industries to shut down for long time and it affected the banking operations.

The outcome of this study suggested that ROA is the influencing factor in shareholders wealth creation. Besides this, there are various external factors affecting the banks performance and ultimately affects the shareholders wealth. Cost reduction should be in the priority. Other supplementary variables should be analyzed to know their effect on shareholders wealth.

\section{References}

Adhikari, S. (2014). Merger and acquisition as an indispinsable tool for strengthening nepalese banking and financial institutions. Lapland: Lapland University of Applied Sciences. Retrieved August 08, 2016, from https://www.theseus.fi/bitstream/handle/10024/75198/Adhikari_Santosh.pdf?sequence=1

Asikhia, 0. \& Adeyinka, S. (2013). Capital adequacy and banks' profitability: an empirical evidence from nigeria. American International Journal od Contemptory Research, 3(10), 87-93.

Bashir, A., Sajid , M. \& Sheikh , S. (2011). The Impact of Mergers and Acquisitions on Shareholders Wealth: Evidence from Pakistan. Middle-East Journal of Scientific Research, 8(1), 261-264. Retrieved 04 10, 2016, from http://www.idosi.org/mejsr/mejsr8(1)11/44.pdf

Caves, R. E. (2003). Effects of Mergers and Acquisitions on the Economy: An Industrial Organization Perspective. Harvard University.

Conyon, M., Girma, S., Thompson, S. \& Wright, P. (2000). The Impact of Mergers and Acquisitions on Company Employment in the United Kingdom. Centre for Research on Globalisation and Labour Markets.

Doytch, N. \& Cakan, E. (2011). Growth Effects of Mergers and Acquisitions: A Sector-level Study of OECD countrie. Journal of Applied Economics and Business Research, 3, 120-129 . 
Eltivia, N., Sudarna, M., Rosidi, L. \& Saraswati, E. (2014). The effect of cost efficiency on stock performance of listed bank in indonesia. International journel of economic research, 3, 50-56.

Institute of management accountants. (1997). Measuring and managing shareholder valur creation. In $\mathrm{H}$. Armitage, \& V. Jog, Business performance management. Montvale: Institute of management accountants.

Jensen, M. C. \& Ruback, R. S. (1983). The market for corporate control. Journal of financial economics, 2, 5-50.

Juma, O. N., Wawire, P. T., Byaruhanga, J., Okaka, O. \& Odera, O. (2012). Impact of bank mergers on shareholders' wealth. International Journal of Business and Social Research (IJBSR), 2(6), November 2012.

Lipton, M. (2006). Mergers waves in 19th, 20th and 21st centuries. York University.

Maditinos, D., Theriou, N. \& Demetriades, E. (2009). The Effect of Mergers and Acquisitions on the Performance of Companies - The Greek Case of Ioniki-Laiki Bank and Pisteos Bank. European Research Studies, XII(2).

Oladipupo, A. \& Okafor, C. (2011). Control of shareholders wealth maximization in Nigeria. Journal of Business systems, governance and ethics, 6(1), 19-24.

Olalekan, A. \& Adeyinka, S. (2013, October). Capital Adequacy and banks' profitability: an empirical evidence from nigeria. International journal of contemporary research, 3, 87-93.

Omah, I., Okolie, J. U. \& Durowoju, S. T. (2013). Mergers and acquisitions: effects on shareholders' value evidence from Nigeria. International Journal of Humanities and Social Science, 3(6), 151-159.

Onikoyi, I. A. \& Awolusi, O. D. (2014). Effects of mergers and acquisitions on shareholders wealth in negerian banking industry. British journal of marketing studies, 2, 52-71.

Roberts, A., Wallace, W. \& Moles, P. (2010). Mergers and acquisitions. Great Britain: Edinburg Business School.

Sharma, V. (2010). Do bank mergers create shareholders value? an event study analysis. Economic paper.

Wang, C. \& Xie, F. (2009). Corporate governance transfer and synergistic gains from merger and acquisitions. The review of financial studies, 22.

Wheelen, T. L. \& Hunger, J. D. (2012). Strategic management and business policy toward global sustainability. Pearson. 